\title{
Effect of Superheating on Properties of Aluminium-Silicon Castings
}

\section{* I. Mousa ** M.T. Elmestekawi}

* Mechanical Engineering Department, Shoubra Faculty of Engineering, Zagazig University. ** Mechanical Engineering Department, Higher Technological Inst. $10^{\text {th }}$ of Ramadan City.

\section{Abstract}

This paper indicated that the strength and hardness of Al-Si alloys are influenced slightly by superheating and Si content. However the ductility $(\delta)$ is affected markedly by pouring temperature (i.e. superheating) and Si content too. For the hypereutectic Al-Si alloy the pouring temperature must be as minimum as possible to obtain the best properties. The Si segregation is influenced also by the Si content.

\section{Introduction}

Al-Si alloys are widely used in practice especially in automobile industry. This is due to its good properties, such as castability, low coefficient of thermal expansion, weldability, corrosion resistance, machinability, wear resistance, and good sliding properties [1].

Good mechanical properties for $\mathrm{Al}-\mathrm{Si}$ alloys can be achieved by grain refinement i.e. inoculating the molten metal with different kinds of inoculants. These inoculants improve and inhance the casting nucleation process for the primary grains and eutectic silicon. The used inoculants depend mainly on the refined phase. The $\alpha$ solid solution is refined with $\mathrm{Ti}$ and $\mathrm{B}$, but the eutectic silicon is refined with $\mathrm{Sr}$. On other hand the refining of primary silicon of hyper-eutectic Al-Si alloys is achieved by $\mathrm{P}$. The $\mathrm{La}, \mathrm{Ce}, \mathrm{Yt} \ldots$ etc are also used for inhancing the nucleation process. Not only the inoculation of molten metal affects the solidification process but also the pouring temperature (i.e. superheating), rate of mould diffusivity, and melt composition [7-9].

Manuscript received from Dr. M.T. ELMESTEKAWI on : 16 /2/2000 Accepted on : 28/2/2000 Engineering Research Bulletin, Vol 23,No 2, 2000 Minufiya University, Faculty of Engineering, Shebien El-Kom, Egypt, ISSN 1110-1180 
If the pouring temperature increases, the mould wall temperature is also increased. This leads to a decrease in the rate of cooling from the mould wall. In this case the molten alloy would grow into large particles [2]. At the same time, the between grain segregation increases too. Therefore, the mechanical properties are decreased. However, when the superheating decreases, the solidification rate increases. This will exhibits more cellular form i.e. the dendrites are less ramified, which facilitates better feeding [10] as shown in Figure (1). The fast solidification rate introduces also fine grain size due to the increased number of potential nucleants evolved with fewer amounts of eutectic phases. This leads to an improve in the casting properties $[9,11,12]$ The solute undercooling (constitutional undercooling ) is essential for the survival and growth of the nucleated equiaxial grains [9]. The relation between superheating $(\Delta T)$ and number of grains $(N)$ per unit area is shown in Figure $(2)$ [13]. The fine grain structure [i.e. great number of grains N] are achieved at smallest superheating [point 1\&2]. As the value of superheating increases the grain size increases too [i.e. number of grains decreases] and the structure coarser till a definite superheating $\Delta \mathrm{T}_{\mathrm{kr}}$ [point 3]. At higher superheating over $\Delta \mathrm{T}_{\mathrm{kr}}$ the number of grains may increase [point 4] only if there are sufficient number of nuclei are present in the melt. The value of $T_{k r}$ is influenced by the physical properties of the casting material [i.e. latent heat, thermal conductivity, melting point......etc].

The change of the alloy composition affects the solidification range $(\Delta T)$, additionally increasing the solidification range increases the size of the mushy zone [14], which increases the solidification time and decreases the porosity. This is may be due to a longer time available for interdendritic flow but on other hand decreases the mechanical properties due to the evolved coarse grains.

The Al-Si alloys are widely used in practice, and the controlling of the value of superheat before pouring is very important to achieve the required mechanical properties and surface finishing of castings.

Therefore this paper defines the relation between the superheating and the AlSi alloys properties. 


\section{Experimental procedure:}

This investigation emphasizes the effect of superheating on the properties of Al-Si alloys. This occurred in the following steps.

\section{Materials:}

Commercial Al-Si alloys were used. The chemical analysis are given in Table1.

Table (1): chemical composition of Al-Si alloys.

\begin{tabular}{|c|c|c|c|c|c|c|c|c|}
\hline Al-Si alloy & Si \% & $\mathrm{Cu} \%$ & $\mathrm{Mg} \%$ & $\mathrm{Fe} \%$ & $\mathrm{Mn} \%$ & $\mathrm{Zn} \%$ & $\mathrm{~Pb} \%$ & $\mathrm{Al} \%$ \\
\hline Al-Si 7\% & 7.00 & 0.08 & 0.09 & 0.40 & 0.21 & 0.04 & 0.01 & rest \\
Al-Si 12\% & 12.60 & 0.05 & 0.07 & 0.45 & 0.22 & 0.04 & 0.01 & rest \\
Al-Si 17\% & 17.45 & 0.03 & 0.04 & 0.40 & 0.20 & 0.04 & 0.01 & rest \\
\hline
\end{tabular}

The raw materials used were in the form of virgin ingots supplied from Nagaa Hammady Aluminium Works.

\section{Melting Procedure:}

The melting process was achieved in a small potan gas crucible furnace

of $2 \mathrm{Kgs}$ molten aluminum capacity. Special precaution were taken into consideration to avoid the casting defects. A3\% coveral 11 is used to cover the surface of molten metal to protect the melt from oxidation. After melting the slag is carefully skimmed off, the degaser of $1 \%$ is used. This is to minimize the oxygen content in the melt and to avoid the formation of bubbles or pinholes. The value of superheating for each melt was monitored with $\mathrm{Ni}-\mathrm{NiCr}$ thermocouple $\mathrm{K}$ type. The value of superheat i.e. temperature over liquidus temperature for all melts are $40^{\circ} \mathrm{C}, 80^{\circ} \mathrm{C}, 120^{\circ} \mathrm{C}$, and $160^{\circ} \mathrm{C}$.

\section{Metallugraphic and mechanical properties:}

The melt was poured in a metallic mould after the melting process, and after controlling the pouring temperature. From each casting specimens prepared for micrographic examination and mechanical properties. The $0.5 \%$ HF etchant was used for revealing the grain structure. 


\section{Results and discussion:}

The results showed that the superheating affects the properties of $\mathrm{Al}-\mathrm{Si}$ alloys especially for high silicon content castings.

The examined properties were $\sigma_{u}, \delta \%$ and $\mathrm{HB}$ are given in table (2) and illustrated in Figures 3,4 , and 5.

Figures 3 and 4 show a slight decrease for $\sigma_{u}$ and $H B$ as the superheating $\Delta T$ increases. At the same time $\sigma_{u}$ and $H B$ increases with the Si content. The casting ductility $\delta \%$ not only influenced markedly as superheating increases, but also by increasing Si\% content as shown from Figure (5).

Table (2): Effect of superheating $[\Delta \mathrm{T}]$ on mechanical properties of $\mathrm{Al}-\mathrm{Si}$ alloys.

\begin{tabular}{|c|c|c|c|c|c|c|}
\hline $\begin{array}{l}\text { Exp. } \\
\text { No. }\end{array}$ & $\begin{array}{c}\mathrm{Si} \\
\text { content }\end{array}$ & $\begin{array}{l}\text { Pouring } \\
\text { Temp. } C^{\circ}\end{array}$ & $\begin{array}{l}\text { Super } \\
\text { Heating } \\
\Delta \mathrm{TC}^{\circ}\end{array}$ & $\begin{array}{l}\text { Average } \\
\text { Value of } \\
\sigma_{\text {o }}(\mathrm{MPa})\end{array}$ & $\begin{array}{l}\text { Average } \\
\text { value of } \\
\delta \%\end{array}$ & $\begin{array}{l}\text { Average } \\
\text { value of } \\
\mathrm{HB}\end{array}$ \\
\hline 1 & \multirow{4}{*}{$\frac{2}{2}$} & 680 & 40 & 130 & 15.5 & 125 \\
\hline 2 & & 720 & 80 & 120 & 16.5 & 110 \\
\hline 3 & & 760 & 120 & 110.5 & 17 & $105^{\circ}$ \\
\hline 4 & & 800 & 160 & $\because 100$ & 18.5 & 95 \\
\hline 5 & \multirow{4}{*}{$\frac{\stackrel{2}{2}}{\frac{1}{2}}$} & 620 & 40 & 150 & 8 & 147 \\
\hline 6 & & 660 & 80 & 150 & 12 & $\because 145$ \\
\hline 7 & & 700 & 120 & 140 & $\because 14$ & 135.5 \\
\hline 8 & & 740 & 160 & 110.5 & 16 & 105.5 \\
\hline 9 & \multirow{4}{*}{$\frac{\stackrel{2}{2}}{\frac{2}{2}}$} & 700 & 40 & 170 & 4 & 164 \\
\hline 10 & & 740 & 80 & $\therefore 162$ & 5.5 & 156 \\
\hline 11 & & 780 & 120 & 159 & 6 & 150 \\
\hline 12 & & 820 & 160 & 160 & 8 & 145 \\
\hline
\end{tabular}

The changes in properties ( $\sigma_{u}$ and $\mathrm{HB}$ ) are attributed to the dispersion strengthening by the primary $\beta$ pkase. On other hand $\delta$ is affected pronouncly by increasing the $\mathrm{Si} \%$ content ard the value of superheating $\Delta \mathrm{T}$ i.e. Figure (5). This is due to the formation of coarse grains as a function of superheating beside the grain segregation for the $\mathrm{Si} \%$ ontent as shown in Figure $(6 \mathrm{a}, 6 \mathrm{~b})$ 
and Figure $(7 \mathrm{a}, 7 \mathrm{~b})$ where the Si content reached in some places in fracture to $26.97 \%$ [Exp. 12].

The microstructure is influenced also markedly by the value of superheating $(\Delta \mathrm{T})$ as shown in Figures ( $8 \mathrm{a}, \mathrm{b}, \mathrm{c}, \mathrm{d}, \mathrm{e}, \mathrm{f}$ ) where the samples with smaller superheating $\Delta \mathrm{T}$ exhibits better (fine) microstructure which in turn affected the strength, at the same time increasing the Si \% content decreases sharply the value of $(\delta)$.

The obtained results are attributed to the effect of superheating on the microstructure and in turn on the mechanical properties. The superheating affects on both the rate of heat flow from the casting and the mould, where the rate of heat flow becomes smaller at high superheating. This is due to the smaller evolved heat gradient in the casting and the mould wall. Also the superheating eliminate the formation of constitutional undercooling which has a great influence on the solidification process of all alloys.

The results obtained from this investigation show that, higher superheating exhibits coarser grains but, low superheating introduces fine grain structure as shown in Figure $8 \mathrm{a}, \mathrm{b}$. The same results were observed in Figure $8 \mathrm{c}, \mathrm{d}$ and $8 \mathrm{e}, \mathrm{f}$. where the superheating leads to coarse primary silicon especially for hypereutectic alloy as shown in Figure $8 \mathrm{c}, \mathrm{d}$. This is due to the higher superheating which permits longer time for primary silicon formation. The formation of coarse a circular crystals reduces sharply the alloy ductility, also the silicon precipitates in large irregular shape which have an adverse influence on the mechanical properties. Therefore, the increase of $\sigma_{u}$ with smaller superheating $(\Delta \mathrm{T})$ are due to the fine structure, as shown in Figures 3,4,5 and Figures $8 \mathrm{a}, \mathrm{c}$,e. On other hand the smaller value of $\sigma_{\mathrm{u}}$ is due to the formed coarser grain structure i.e. Figures 3,4,5 and Figure 8 b, d,f.

\section{Statistical study for results by using T-test :}

T-test is a type of statistical tests that is used for if the hypothesis that the two normal populations have equal means or not. The real difference between the two results means that there is an improvement in the developed composition. This technique is utilized to test the hypothesis that the change of casting 
conditions $\left(T_{p}\right.$ and $\left.\Delta T\right)$ affects the properties of cast $\left(\sigma_{u}, \delta \%\right.$ and $\left.H B\right)$ as the composition of Al-Si is changed.

In this part we compared the change in results obtained by changing casting conditions of $\mathrm{Al}-\mathrm{Si}$ on the cast properties of $\mathrm{Al}-\mathrm{Si} 12 \%$ and $\mathrm{Al}-\mathrm{Si} 17 \%$ compared to that of $\mathrm{Al}-\mathrm{Si} 7 \%$ as a base study. Table (3) shows a statistical verifications of experimental results.

Table (3): Statistical verification of the experimental results.

\begin{tabular}{|c|c|c|c|c|c|c|}
\hline Properties & \multicolumn{2}{|c|}{$\sigma_{u}$} & \multicolumn{2}{c|}{$\delta \%$} & \multicolumn{2}{c|}{ HB } \\
\hline $\begin{array}{c}\text { The used } \\
\text { aluminum } \\
\text { alloys }\end{array}$ & $\begin{array}{c}\text { Al-Si 7\% } \\
\text { Al-Si 12.6\% }\end{array}$ & $\begin{array}{c}\text { Al-Si 7\% } \\
\text { Al-Si 17.6\% }\end{array}$ & $\begin{array}{c}\text { Al-Si 7\% } \\
\text { Al-Si 12.6\% }\end{array}$ & $\begin{array}{c}\text { Al-Si 7\% } \\
\text { Al-Si 17.6\% }\end{array}$ & $\begin{array}{c}\text { Al-Si 7\% } \\
\text { Al-Si 12.6\% }\end{array}$ & $\begin{array}{c}\text { Al-Si 7\% } \\
\text { Al-Si 17.6\% }\end{array}$ \\
\hline$|T|$ & 3.9686 & 11.81 & 4.81 & 21.23 & 4.92 & 12.04 \\
\hline T & 1.94 & 1.94 & 1.94 & 1.94 & 1.94 & 1.94 \\
\hline $\begin{array}{c}\text { Statistical } \\
\text { results }\end{array}$ & \multicolumn{6}{|c|}{ All results indicate a real difference in all tests } \\
\hline
\end{tabular}

All results are compared to the confidence limit of $95 \%$. A detailed calculations are illustrated in appendix A.

\section{Conclusions:}

The statistical analysis using T-test verified the obtained experimental results therefore:-

1- the Al-Si castings strength and hardness are influenced slightly by increasing the superheating $\Delta \mathrm{T}{ }^{\circ} \mathrm{C}$.

2- the Al-Si castings ductility increases as superheating decreases.

3- The Al-Si castings ductility is influenced markedly by $\mathrm{Si}$ content and superheating.

4- The segregation is significantly as affected the Si content increases.

5- The superheating must be small as possible for better mechanical properties especially for eutectic and hypereutectic Al-Si castings. 


\section{References:}

1- Dr Ben Heshmatpour, light metals, , 1997, pp 801-808.

2- Zhao Hengxian, light metals, 1993, pp 821-824.

3- M. H. Kim et.al. , light metals, 1998, pp 991.

4- Wolfgang schneider, light metals, 1993, pp 815-820.

5- Shu Zu Lu et.al., , light metals, 1995 , pp 989-993.

6- Zhao Heng et.al. , light metals, 1995, pp 995-998.

7- Dr. U. Harinath et.al. $50^{\text {th }}$ international foundry conference, Cairo, Nov. 1983, No. 20.

8- K. Muller, Arab foundry symposium, Nov. 1997, IV-3.

9- J. A. Spittle et.al., light metals, 1997, pp 795-800.

10- Kenneth Nilsson, $50^{\text {th }}$ international foundry conference, Cairo, Nov. 1983, No. 22.

11- Jain Wan et.al. , light metals, 1998, pp 1065-1070.

12- H. Abdel Kader ,El-Sibaka, Sep. 1993, pp 23-37.

13- Zlievarenstvo nezeleznych Kovov. SNTL Technicke literatory, Praha 1988 , Czech republic.

14- A. Ahmed et. al. , light metals, 1979, pp 879-889.

\section{Appendix:}

- The average value of $\delta \%$ for the Al-Si $7 \%$ and $\mathrm{Al}-\mathrm{Si} 17.45 \%$.

- Assume there is a difference between the two results.

- Enter two-tailed significance level : $\mathrm{P}=0.05$

- Sample sizes:

$\mathrm{n} 1=$ length $(\mathrm{d} 1) \mathrm{n} 2=$ length $(\mathrm{d} 2)$

$$
\mathrm{n} 1=4
$$$$
\mathrm{n} 2=4
$$

- Means:

$\mathrm{m} 1=\operatorname{mean}(\mathrm{d} 1) \mathrm{m} 2=\operatorname{mean}(\mathrm{d} 2)$

$\mathrm{ml}=19.875$ $\mathrm{m} 2=5.875$

$$
\mathrm{d} 1=\left\{\begin{array}{c}
18.5 \\
17 \\
16.5 \\
15.5
\end{array}\right\} \quad \mathrm{d} 2=\left\{\begin{array}{c}
8 \\
6 \\
5.5 \\
4
\end{array}\right\}
$$

- Standard deviations:

$$
\begin{array}{ll}
\mathrm{c} 1=0,1.3 & \mathrm{c} 2=0,1 . .3 \\
\mathrm{D} 1_{\mathrm{cl}}=\left(\mathrm{d} 1_{\mathrm{cl}}\right)^{2} & \mathrm{D} 2_{\mathrm{c} 2}=\left(\mathrm{d} 2_{\mathrm{c} 2}\right)^{2}
\end{array}
$$

$$
\mathrm{S} 1=\sqrt{\frac{\sum \mathrm{D} 1}{\mathrm{n} l}-\left(\frac{\sum \mathrm{d} l}{\mathrm{n} l}\right)^{2}}
$$$$
\mathrm{S} 2=\sqrt{\frac{\sum \mathrm{D} 2}{\mathrm{n} 2}-\left(\frac{\sum \mathrm{d} 2}{\mathrm{n} 2}\right)^{2}}
$$ 
- Degrees of freedom : $\phi=n 1+n 2-2$

$$
\phi=6
$$

- Est. standard error of the difference :

$$
S=\sqrt{\frac{S 1^{2}+S 2^{2}}{\phi}}
$$

$$
D 1=\left\{\begin{array}{c}
342.25 \\
289 \\
272.25 \\
240.25
\end{array}\right\} \quad D 2=\left\{\begin{array}{c}
64 \\
36 \\
30.25 \\
16
\end{array}\right\}
$$

$S=0.73243$

- T Statistic :

$$
\mathrm{t}=\frac{\mathrm{m} 1-\mathrm{m} 2}{\mathrm{~S}} \sqrt{\frac{\mathrm{n} 1^{*} \mathrm{n} 2}{\mathrm{n} 1+\mathrm{n} 2}} \quad \mathrm{t}=21.23927
$$

- From tables at $\mathrm{P}=0.05$ and $\phi=6 \quad \mathrm{~T}=1.94$

- Reject the null hypothesis if $|t|<T . \quad|t|>T$

There is a real difference between the two results.

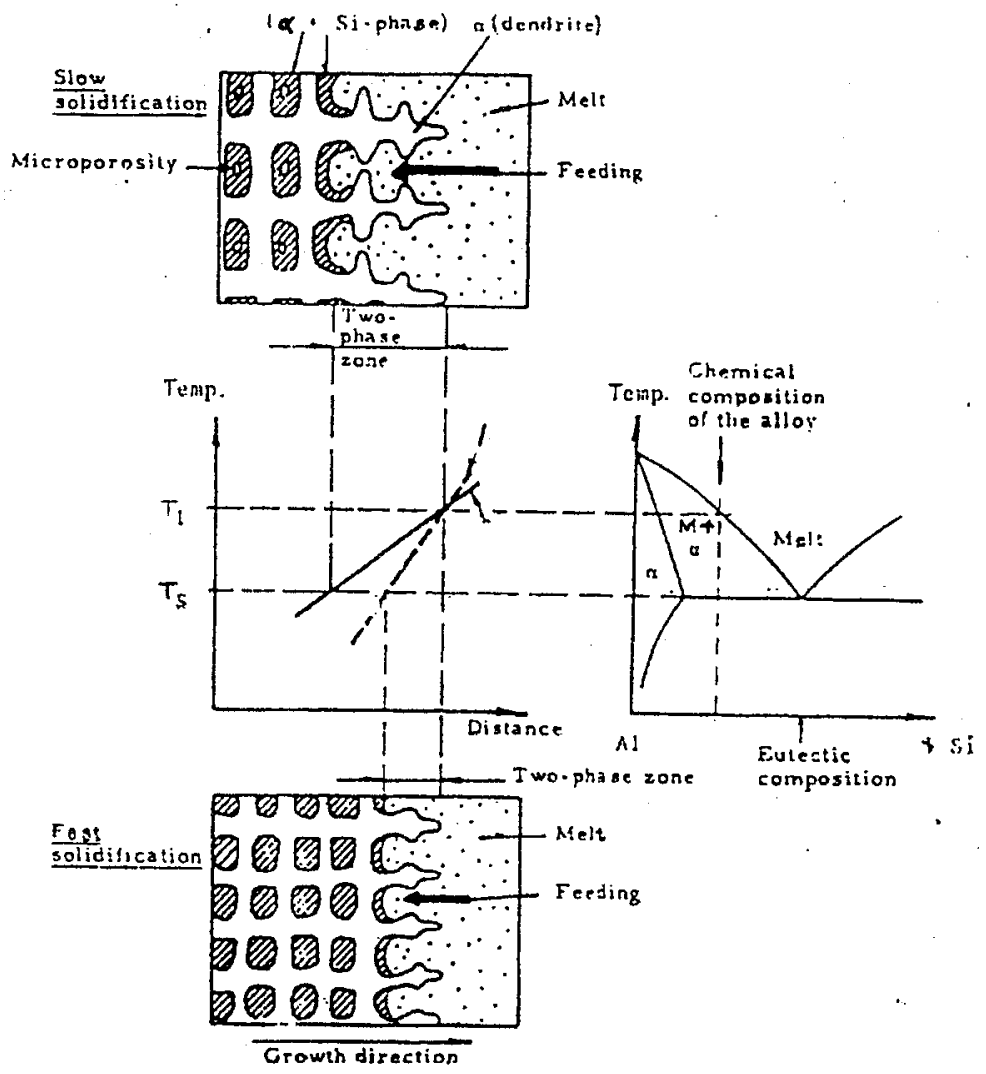

Figure (1) Schematic presentation of micro-feeding conditions at various solidification rates of hypoeutectic Al-Si alloys [10]. 


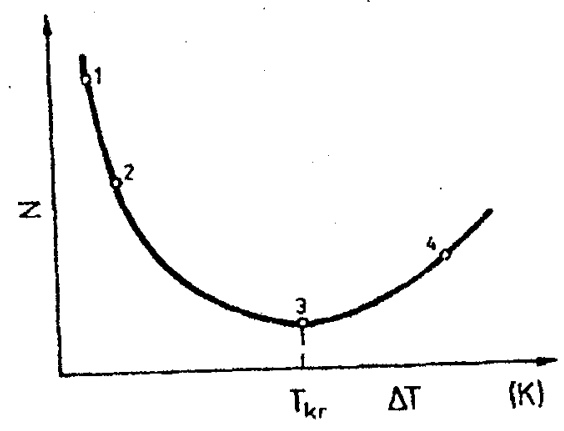

Figure (2) Effect of superheating $\Delta \mathrm{T}$ on grain size

$\mathrm{N}=$ no. of grains $/ \mathrm{cm}^{2}-\Delta \mathrm{T}$ superheating

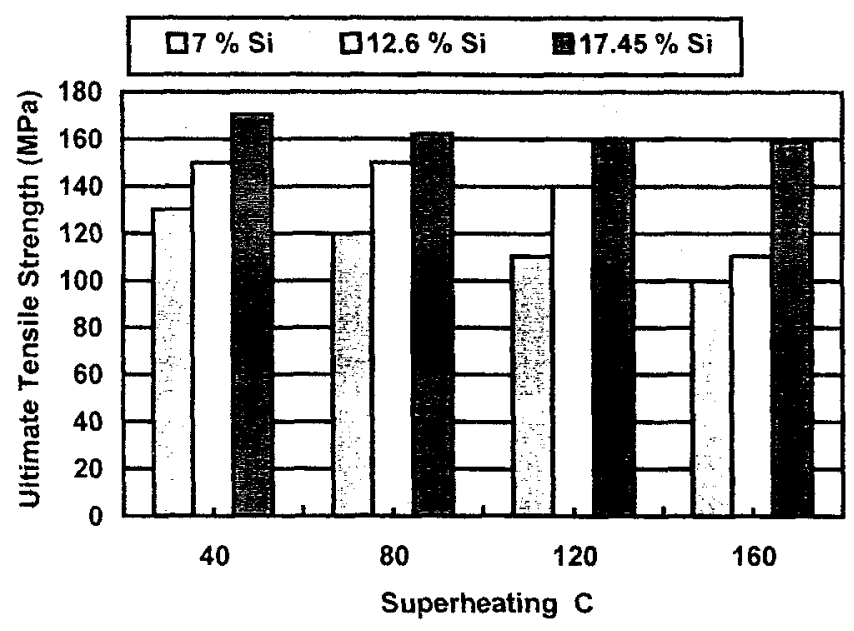

Figure (3) Effect of superhẹating $(\Delta \mathrm{T})$ on Ultimate tensile strength $\left(\sigma_{\mathfrak{u}}\right)$

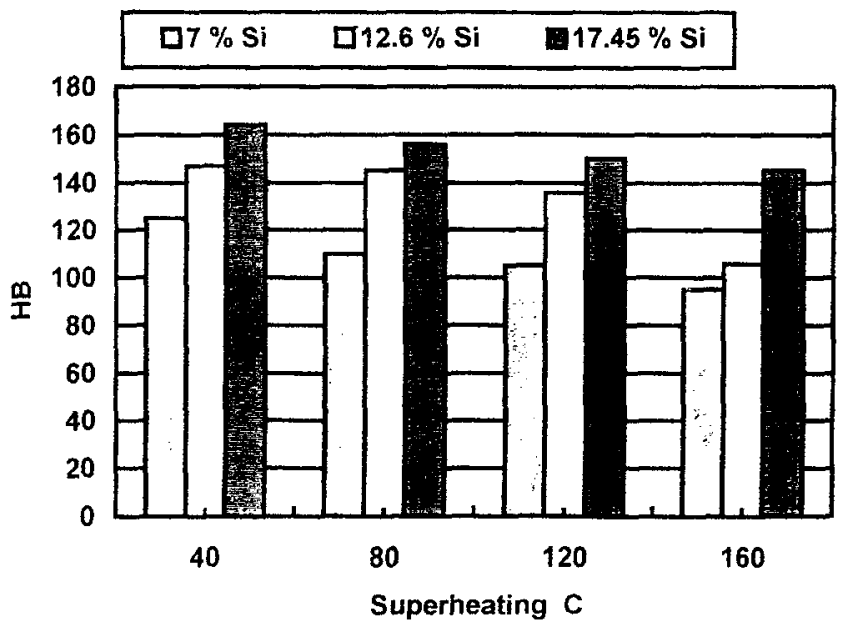

Figure (4) Effect of superheating $(\Delta T)$ on Hardness $(\mathrm{HB})$ 


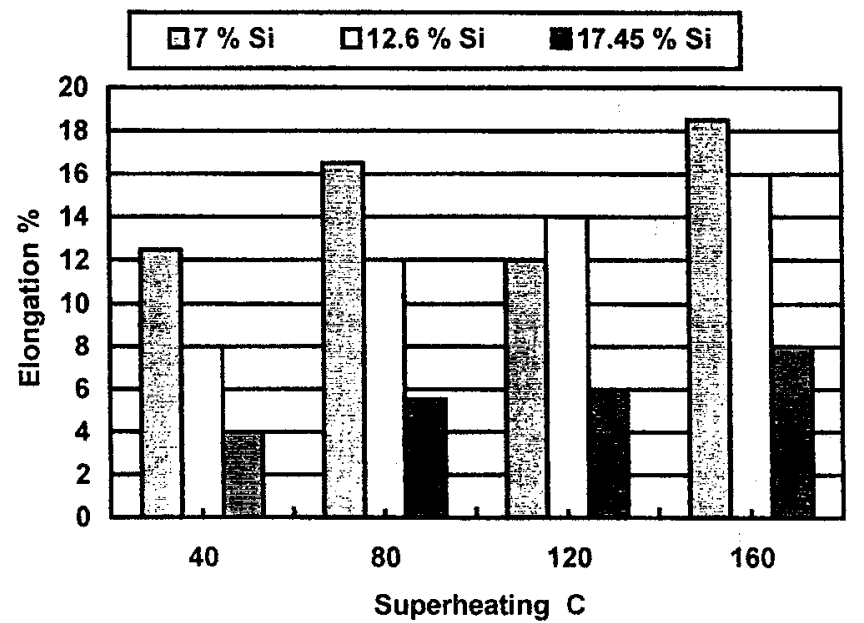

Figure (5) Effect of superheating $(\Delta \mathrm{T})$ on elongation $\%(\delta)$

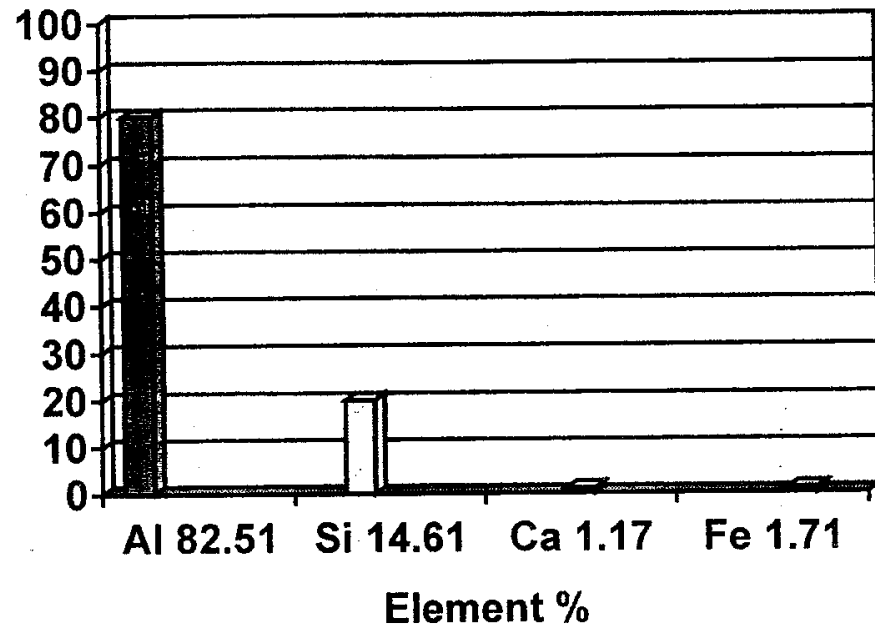

Figure (6a)

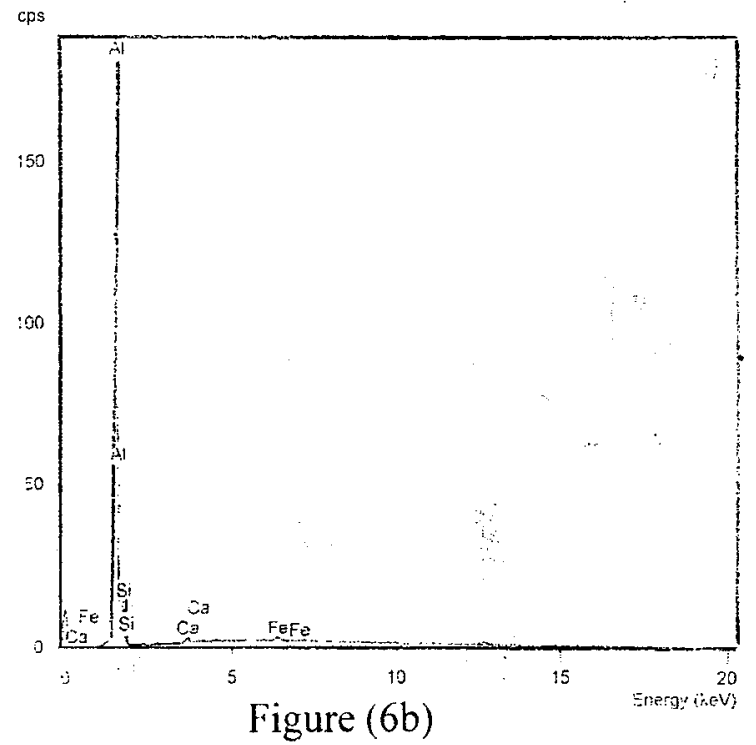

Figure (6 a.b) Spectrum microprobe analysis of the phases in the Al-Si 7\%

alloy [exp.4] 


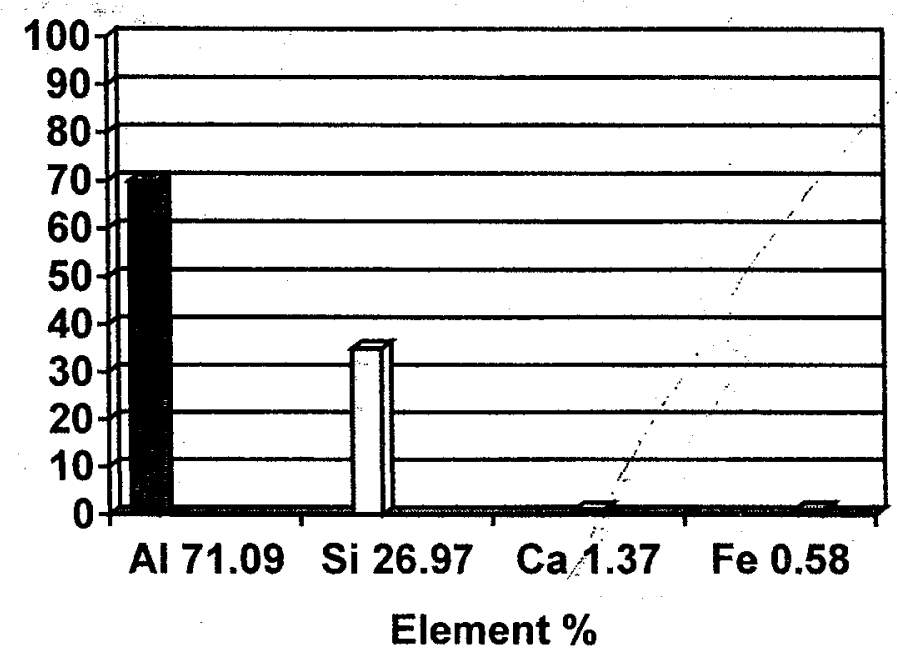

Figure (7a)

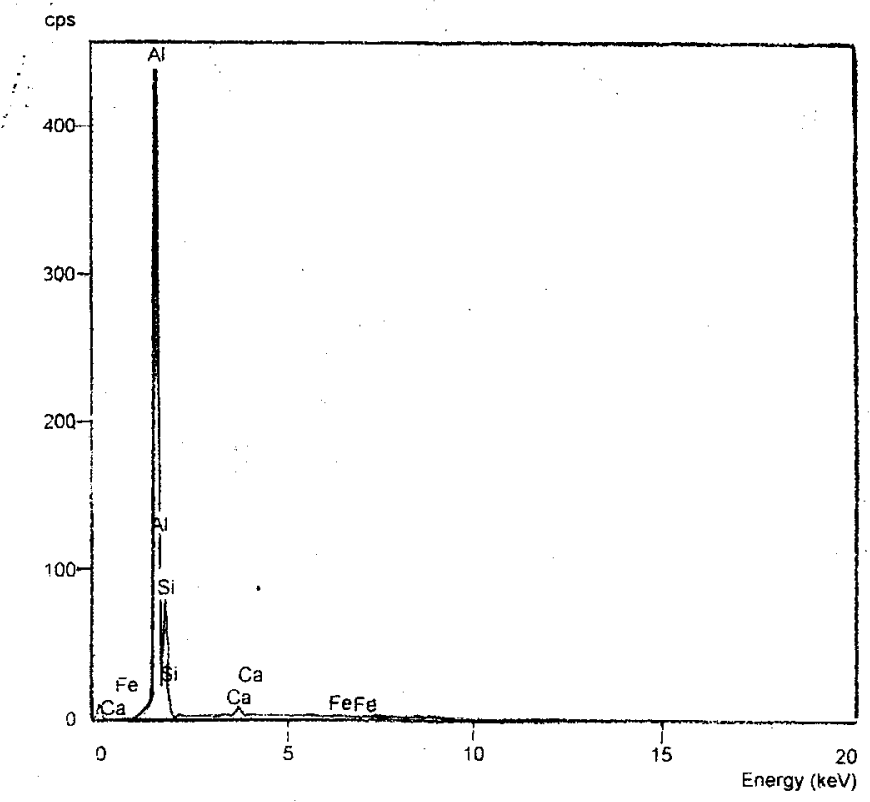

Figure (7b)

Figure (7 a,b) Spectrum microprobe analysis of the phases in the Al-Si $17.45 \%$ alloy [exp.9] 


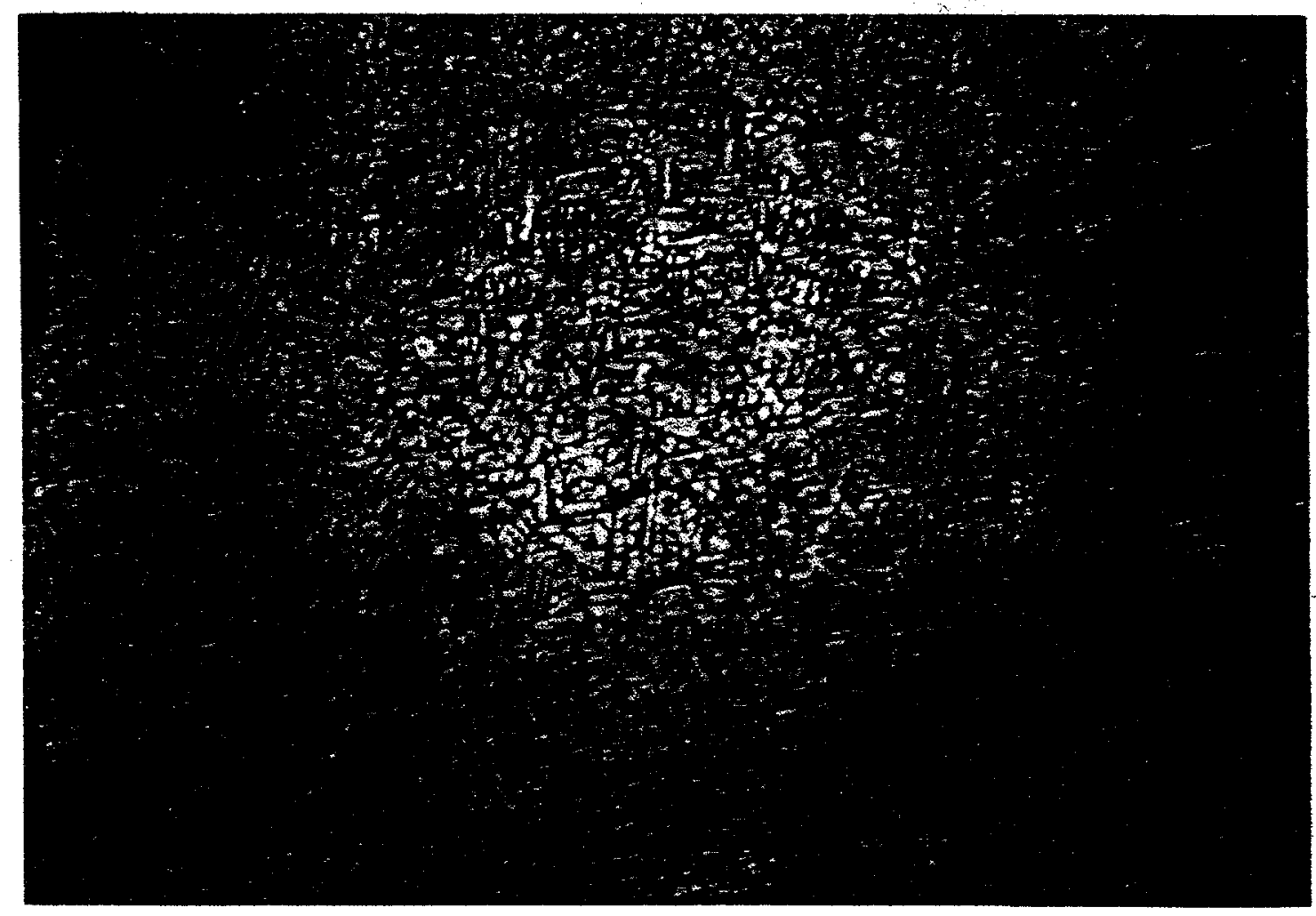

Figure (8a) $\times 100$ [exp.1]

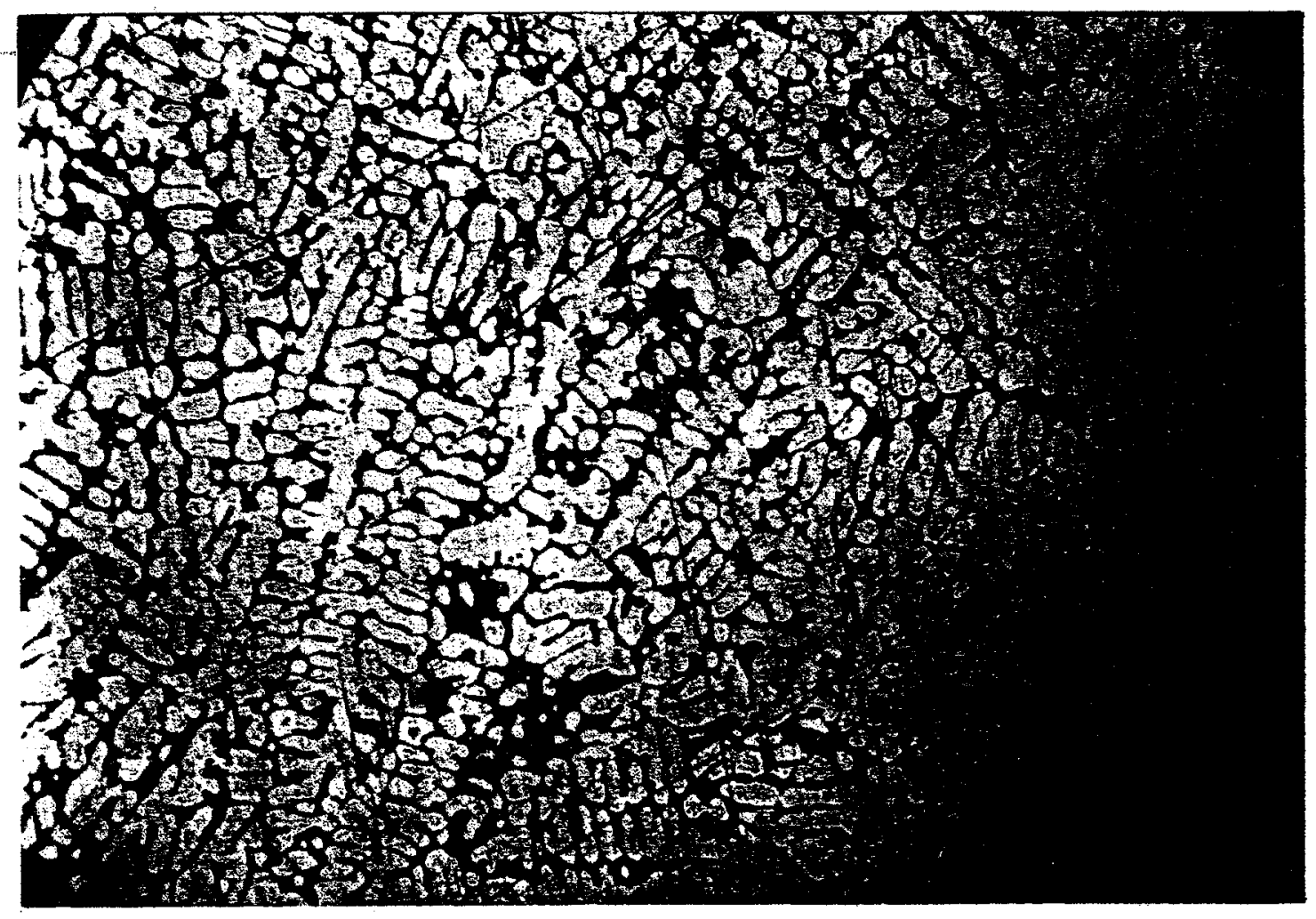

Figure $(8 b) \times 100$ [exp.4] 


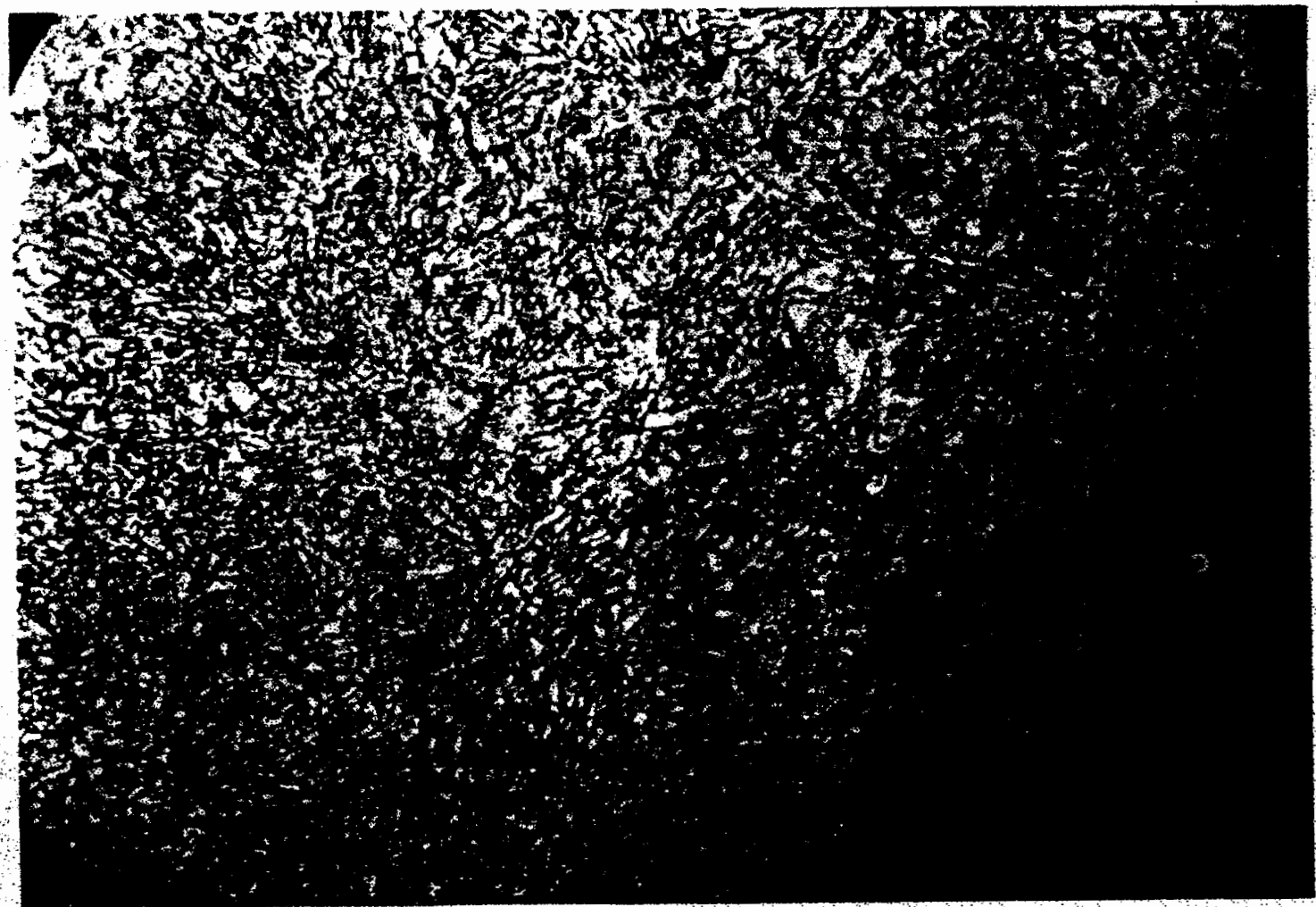

Figure (8c) $\times 100$ [exp.5]

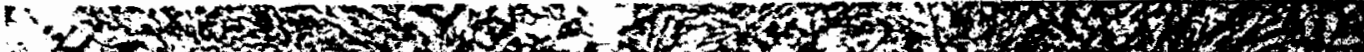

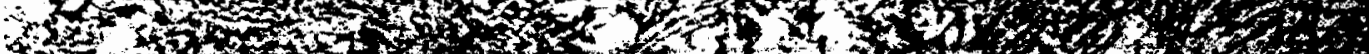

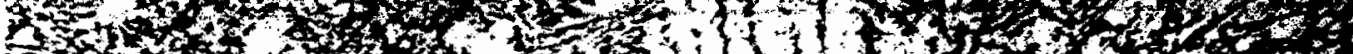

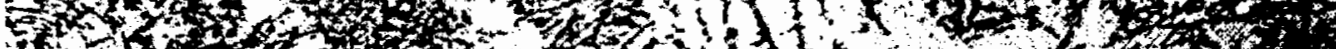

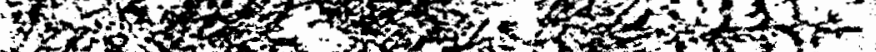

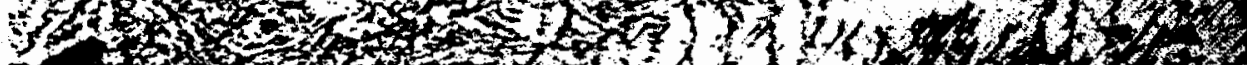

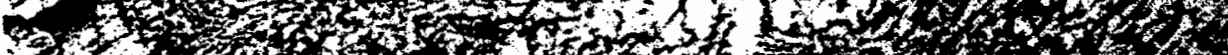

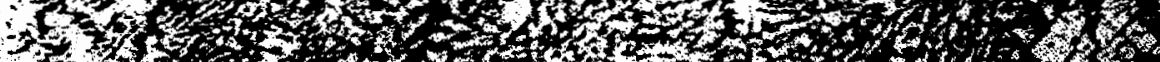

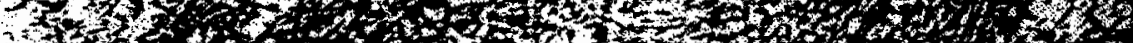

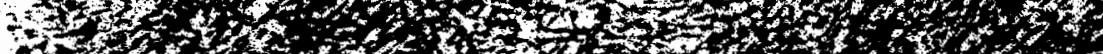

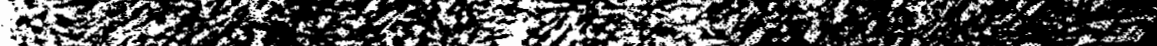

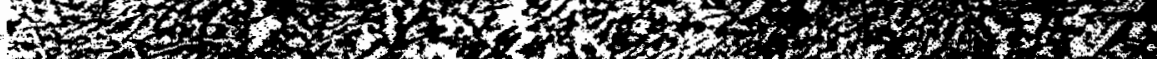

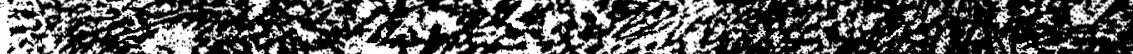

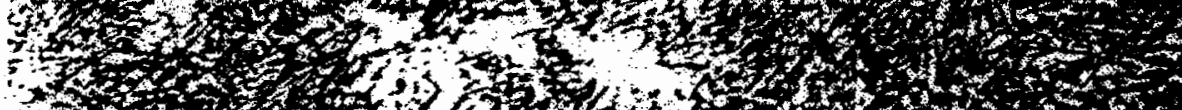

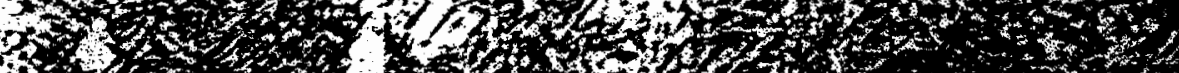

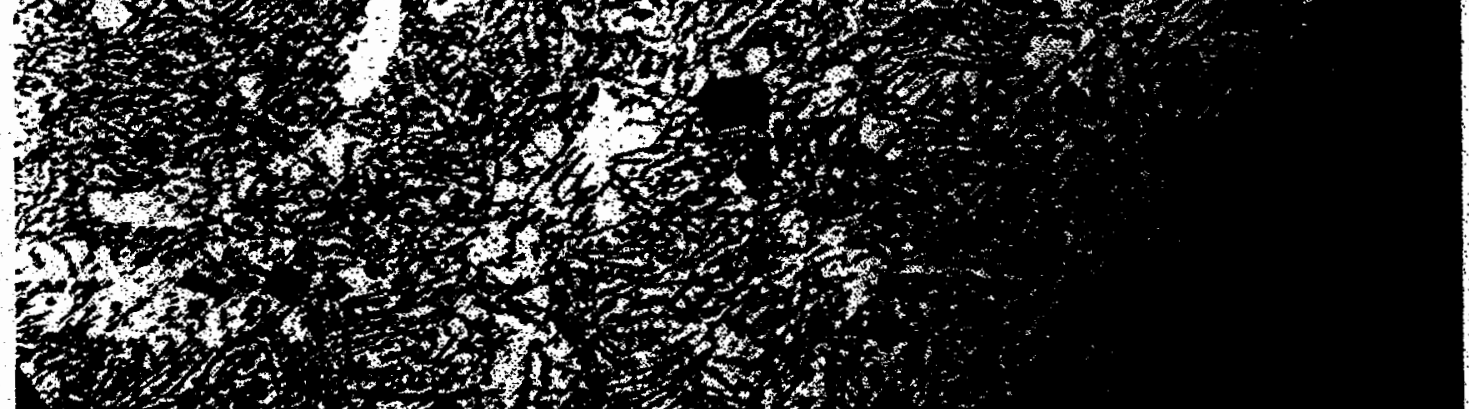

Figure $(8 d) \times 100[\exp .8]$ 


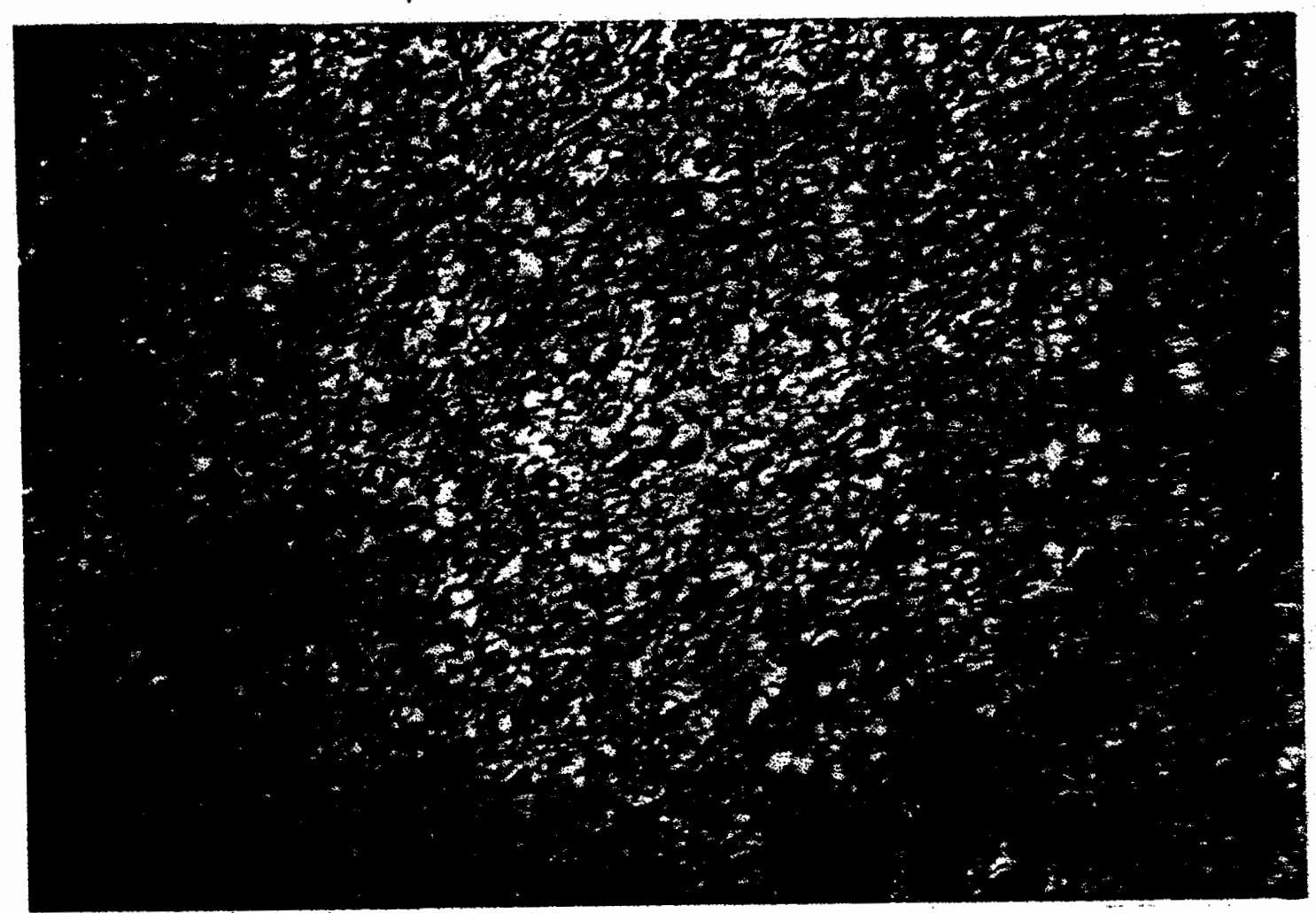

Figure $(8 \mathrm{e}) \times 100$ [exp.9]

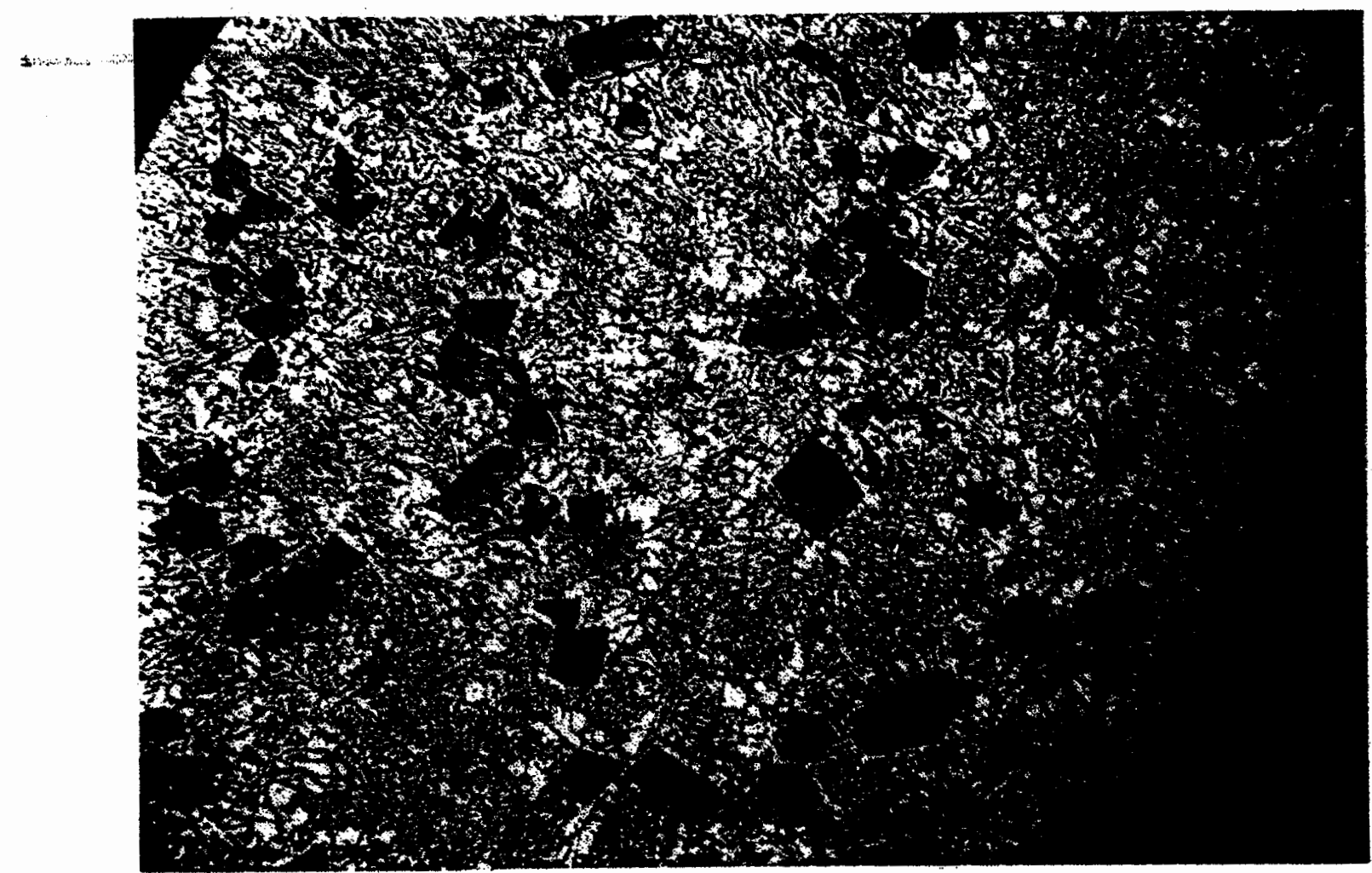

Figure $(8 f) \times 100[\exp .12]$ 


\section{تأثير التسخين الفائق على خواص مسبوكات الألومنيوم سيليكون الفي علئ}

\section{ملخــــص}

يــدل البحـث على أن المتانـة والصـلادة لسـبائك الألومنيسوم سـيليكون تتـأثر قليـلاً بالتسخين الفائق ونسبة وجود السيليكون بينما تتـأثر الممطوليسة بشـكل واضسح بالتسـخين

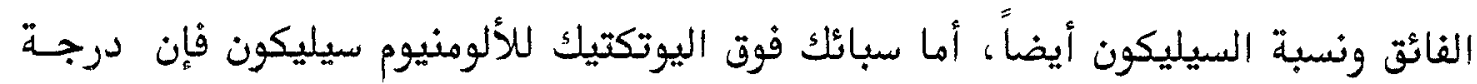

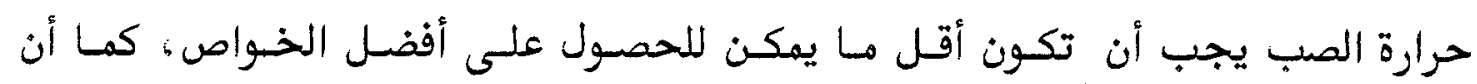
ترسيبات السيليكون تتأثر بنسبة وجوده. 